\title{
Chronology of the
}

\section{Life of Agesilaus}

\begin{tabular}{|c|c|}
\hline YEAR & EvEnTs \\
\hline $443 / 2$ & Birth \\
\hline $43 \mathrm{I}$ & Outbreak of the Peloponnesian War \\
\hline 425 & Surrender of the Spartans at Sphacteria \\
\hline $42 \mathrm{I}$ & Peace of Nicias \\
\hline $4 \mathrm{I} 8$ & First Battle of Mantineia \\
\hline 4 I 5 & $\begin{array}{l}\text { Athenian expedition to Sicily } \\
\text { Alcibiades in exile in Sparta }\end{array}$ \\
\hline $4 \mathrm{I} 2 / \mathrm{II}$ & Treaties between Sparta and Persia to defeat Athens \\
\hline 405 & Lysander's victory at Aegospotami \\
\hline 404 & Surrender of Athens to Sparta \\
\hline 403 & Lysander superseded by King Pausanias \\
\hline $40 \mathrm{I}$ & $\begin{array}{l}\text { Rebellion of Cyrus the Younger against Artaxerxes } \\
\text { Agesilaus' marriage to Cleora (?) }\end{array}$ \\
\hline 400 & $\begin{array}{l}\text { Spartan aid to Greek cities of Asia Minor } \\
\text { Beginning of Elean War } \\
\text { Birth of his son, Archidamus (?) }\end{array}$ \\
\hline 399 & Dercylidas replaces Thibron in Asia Minor \\
\hline 398 & $\begin{array}{l}\text { End of Elean War } \\
\text { Death of King Agis } \\
\text { Agesilaus' accession to Spartan throne }\end{array}$ \\
\hline 397 & $\begin{array}{l}\text { Conspiracy of Cinadon } \\
\text { Dercylidas' truce with Tissaphernes } \\
\text { News of Persian naval preparations reaches Sparta }\end{array}$ \\
\hline 396 & $\begin{array}{l}\text { Agesilaus sails for Asia Minor; Aulis incident } \\
\text { Agesilaus' rejection of Lysander's influence }\end{array}$ \\
\hline 395 & $\begin{array}{l}\text { Return of Lysander to Sparta; his death at Haliartus } \\
\text { King Pausanias banished from Sparta } \\
\text { Agesilaus' victory at Battle of Sardis } \\
\text { Outbreak of the Corinthian War }\end{array}$ \\
\hline
\end{tabular}


xviii Chronology of the Life of Agesilaus

394

393

392

39 I

390

389

388

387

$387 / 6$

386

385

384

383

382

$38 \mathrm{I}$

380

379

$379 / 8$

378

377

376

375

$375 / 4$

373

37 I
Agesilaus' recall from Asia Minor

Battle of Nemea

Battle of Cnidus

Battle of Coroneia

Agesilaus disarms political opponents in Sparta

Antalcidas negotiates at Sardis

Peace Conference at Sparta

Agesilaus' first campaign in the Corinthia

Agesilaus' second invasion of the Corinthia

Incident with Theban envoys at Perachora

Agesilaus' first campaign in Acarnania

Agesilaus' second campaign in Acarnania

King Agesipolis' campaign against Argos

As navarch, Antalcidas negotiates in Persia

Spartan-Persian accord to end fighting

Negotiation and signing of the King's Peace

Dissolution of the Boeotian Confederacy

Agesipolis' campaign against Mantineia

Agesilaus' intervention against Phlius

Revival of Olynthian Confederacy (?)

Appeals for Spartan aid against Olynthus

Agesilaus begins siege of Phlius

Phoebidas seizes the Theban Cadmeia

Campaign against Olynthus

King Agesipolis' death at Olynthus

Surrender of Olynthus

Capitulation of Phlius

Acme of the Spartan Hegemony

Liberation of Thebes from Spartan control

King Cleombrotus' campaign in Boeotia

Sphodrias incident

Athens forms the Second Athenian League

Agesilaus' first campaign in Boeotia

Passage of the Aristoteles Decree

Agesilaus' second campaign in Boeotia

Cleombrotus' abortive invasion of Boeotia

Naval warfare between Athens and Sparta

Spartan defeat at Tegyra

Spartan defeat at Alyzeia

Peace Conference

Common Peace established

Resumption of warfare at sea

Theban destruction of Plataea

Peace Conference at Sparta

Battle of Leuctra

Peace Conference at Athens 
Revival of Mantineia

Agesilaus' invasion of Arcadia

First Theban invasion of Peloponnesus

Agesilaus' defense of Sparta; uprisings quelled

Liberation of Messenia

Alliance between Sparta and Athens

369 Second Theban invasion of Peloponnesus

$368 \quad$ Philiscus' negotiations at Delphi

Archidamus' Tearless Victory in Arcadia

367 Peace Conference at Sardis; Epaminondas' success

Third Theban invasion of Peloponnesus

Agesilaus' mercenary service with Ariobarzanes

Corinth and Phlius make peace with Thebes

Theban decision to launch a fleet

Pelopidas' death

Agesilaus' return to Sparta (?)

362 Fourth Theban invasion of Peloponnesus

Second Battle of Mantineia; Epaminondas' death

Peace Conference; isolation of Sparta

$36 \mathrm{I}$

$359 / 8$

Agesilaus' mercenary service in Egypt

Agesilaus' death on return voyage to Sparta

All dates in the book are B. C. I give the Julian date where possible (37I) or the archon year $(387 / 6)$ when a more precise date cannot be determined. Because the Athenian archon year began in late June or early July in the Julian calendar, and ended in summer of the following year, it is usually expressed in this way: $(387 / 6)$. For discussion of the dating problems associated with the reign of Agesilaus, see my "Etude chronologique sur le règne d'Agésilas," Ktema 7 ( 982$): 28$ I -96 . 

Agesilaus and the Failure of Spartan Hegemony 
